\title{
Malaysian Hournal of Microbiology \\ Cloning and expression of hyaluronan synthase (hasA) in recombinant Escherichia coli BL21 and its hyaluronic acid production in shake flask culture
}

\author{
Zee Wei Lai ${ }^{*}$ and Chee How Teo $^{2}$
}

\author{
${ }^{1}$ School of Biosciences, Faculty of Health and Medical Sciences, Taylor's University Lakeside Campus, No. 1, Jalan \\ Taylors, 47500 Subang Jaya, Selangor Darul Ehsan, Malaysia. \\ ${ }^{2}$ Center for Research in Biotechnology for Agriculture, Level 3, Research Management and Innovation Complex, \\ University of Malaya, Lembah Pantai, 50603 Kuala Lumpur, Malaysia \\ Email: zeewei.lai@taylors.edu.my
}

Received 25 April 2019; Received in revised form 19 June 2019; Accepted 26 June 2019

\begin{abstract}
Aims: Hyaluronic acid $(\mathrm{HA})$ is a high molecular weight polymer and a major component of mucoid capsule in bacteria and extracellular matrix (ECM) of vertebrate tissue. Due to its unique characteristics, HA is used extensively in medical and cosmetic field. However, because of the exotoxins production from animal tissues extraction and Streptococcus zooepidemicus, HA production by recombinant microorganisms has gained interest. The present study was aimed at cloning of hasA gene in Escherichia coli and optimization of the medium components for HA production.

Methodology and results: A fragment of an approximate size of $1.5 \mathrm{~kb}$ that encodes the hyaluronan synthase (has $A$ ) gene from S. zooepidemicus ATCC 39920 was amplified by PCR using hasA-specific primers. The hasA gene was ligated into the bacterial expression vector pLbADH and transformed into the expression host, Escherichia coli BL21 strain. Then, genetically engineered $E$. coli strain BL21 was used for the production of HA by fermentation using different glucose concentration (10-50 g/L) and different IPTG concentration $(0.1,0.5$ and $1.0 \mathrm{mM})$ in shake flask culture. Amongst varying glucose concentrations, results showed that $50 \mathrm{~g} / \mathrm{L}$ glucose with nutrient rich media containing nitrogen source was able to produce the highest HA concentration $(0.115 \pm 0.002 \mathrm{~g} / \mathrm{L})$. With addition of $1.0 \mathrm{mM}$ IPTG, HA production reached a peak $0.532 \pm 0.026 \mathrm{~g} / \mathrm{L}$ which is around fivefold higher compared to without IPTG.

Conclusion, significance and impact of study: The has $A$ gene was cloned from $S$. zooepidemicus and successfully expressed in recombinant $E$. coli BL21 cells. This low molecular weight HA is gaining more importance in medical and cosmetic application due to possess pronounced free radical scavenging and antioxidant activities.
\end{abstract}

Keywords: Recombinant E.coli BL21, hyaluronic acid, hyaluronan synthase, IPTG

\section{INTRODUCTION}

Hyaluronic acid (or hyaluronan or $\mathrm{HA}$ ) is a polysaccharide that belongs to glycosaminoglycan family and consists of $D$-glucuronic acid (GlcUA) and $N$-acetylglucosamine (GlcNAc), linked alternately by $\beta-1,3$ and $\beta-1,4$ glycosidic bond. $\mathrm{HA}$ is a high molecular weight linear polysaccharide with the molecular weight ranging from $10^{4}$ to $10^{7} \mathrm{Da}$ (Liu et al., 2011). HA is abundantly present in the umbilical cord, synovial fluid and vitreous humor (eye). Due to its biocompatibility, viscoelasticity and hygroscopicity, HA is extensively used for the treatment of ulcer and burn, in ophthalmology, rheumatology and dermatology (Chong et al., 2005). In conjunction with the properties of HA, it is also widely used in cosmetic products, medicine and specialty foods. According to Widner et al. (2005), the market value of $\mathrm{HA}$ was estimated to be over a billion dollars. The global hyaluronic acid market size is expected to reach USD 15.25 billion by year 2026 according to a new report by Grand View Research, Inc (Grand View Research, 2019).

Previously, HA was extracted from rooster comb. According to a study conducted by Rosa et al. (2012), they concluded that rooster comb was composed of about $90 \% \mathrm{HA}$, making it suitable for extraction. However, use of animal-derived biochemical can be risky due to zoonosis and unpremeditated infection transfer. Hence, currently, HA production from microbial fermentation is the commonly used method to meet the demands of the market. Since the 1980s, HA was produced by fermentation of group C Streptococci (Yamada and Kawasaki, 2005). However, these microorganisms are potential human pathogens, thus making HA purification costly. Genetic engineering of microorganisms for $\mathrm{HA}$ synthesis has allowed HA production from nonpathogenic microorganisms. Once the genes that encode 
for HA biosynthesis pathway were determined, a number of bacteria (Bacillus, Agrobacterium, E. coli and Lactococcus) were genetically modified to express the genes and produce HA. Most of the recombinant hosts used for HA production lacks the hyaluronan synthase (hasA) gene. For bacteria to synthesise HA capsule they must contain the hasA gene. A study conducted by Kumari and Weigel (1997) suggested that incorporation of hasA gene is sufficient for HA biosynthesis when the bacteria is already producing GlcUA and GIcNAc. HA production is commonly observed in Gram-positive bacteria, but by genetic engineering of Gram negative bacteria such as $E$. coli, synthesis of HA has been possible and they can be used as potential host candidate for industrial HA production (Yamada and Kawasaki, 2005). Numerous findings have done using glucose as a sole carbon source for the production of HA with concentrations such as $10 \mathrm{~g} / \mathrm{L}$ of glucose producing 1.8 $\mathrm{g} / \mathrm{L}$ of HA by $S$. zooepidermicus ATCC 35246 (Chong et al., 2005), $40 \mathrm{~g} / \mathrm{L}$ of glucose, producing $0.3-0.4 \mathrm{~g} / \mathrm{L}$ of HA by recombinant Corynebacterium glutamicum ATCC $13032 \mathrm{pJH} 174.1$ (Hmar et al., 2014) and $3.8 \mathrm{~g} / \mathrm{L}$ of HA is produced by recombinant $E$. coli JM109 using $45 \mathrm{~g} / \mathrm{L}$ of glucose (Mao et al., 2009). However, there is less study showed the molecular weight of HA using recombinant strains.

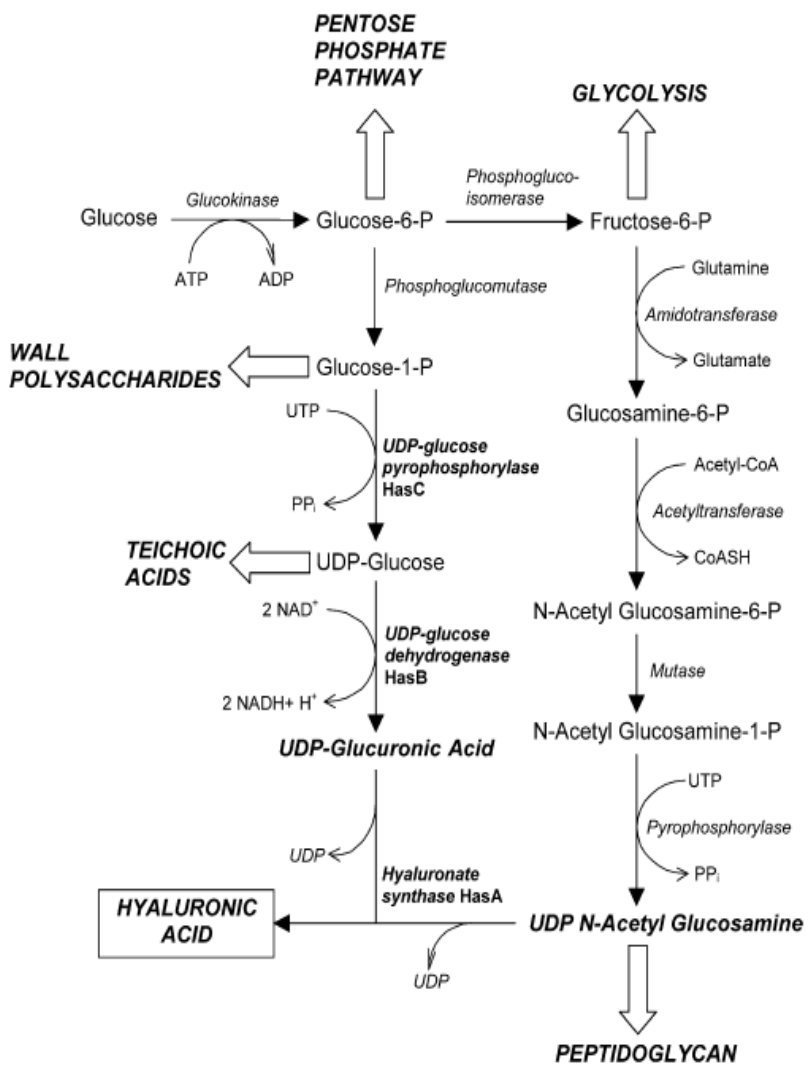

Figure 1: Biosynthetic pathway for the production of $\mathrm{HA}$ in Streptococci (Chong et al. 2005).
Although $E$. coli is a Gram-negative bacterium with the cell wall structure composed of lipopolysaccharide, peptidoglycan and lipoprotein, its metabolic pathway for HA synthesis is very similar to that of Streptococcus spp. Since the biosynthesis pathway of HA is partially similar to cell wall biosynthesis (Figure 1), the heterologous expression of has $A$ gene alone is sufficient to induce production of hyaluronic acid in these organisms. The effort of using recombinant systems to produce HA started when the has $A$ gene encoding for the enzyme that polymerizes UDP-GIcNAc and UDP-GIcUA into hyaluronan was isolated from Streptococcus pyogenes (DeAngelis, 1999). The carbon source essentially provides the necessary energy for both cell growth and exopolysaccharides production (Lai et al., 2011). In addition to that, there is stiff competition for metabolites between HA synthesis and cellular growth due to glucose6-phosphate and fructose-6-phosphate being consumed in the pentose phosphate pathway and glycolysis respectively (Mao et al., 2009). Glucose is the most common carbon source for the production of HA since it allows for high productivities and production. There is limited study on the biosynthetic capabilities of recombinant $E$. coli $\mathrm{BL} 21$ for the production of HA. Hence, the aim of this research study was to clone and express hasA gene into E.coli BL21 and use this recombinant $E$. coli strain BL21 as host in order to explore the biosynthetic capabilities for HA production (concentration and molecular weight) in batch fermentation using shake flask culture.

\section{MATERIALS AND METHODS}

\section{Bacteria strains and plasmid}

Streptococcus equi sub sp. zooepidemicus (American Type Culture Collection ${ }^{\circledR} 39920^{\mathrm{TM}}$ ) was used and stored at $-80{ }^{\circ} \mathrm{C}$ in $50 \%(\mathrm{v} / \mathrm{v})$ glycerol stock. E. coli BL21 were used as the recombinant host cell and plasmid pLbADH was used as bacterial expression vector.

\section{Isolation of has $A$ gene using PCR amplification from S. zooepidemicus}

The has $A$ gene was isolated from $S$. zooepidemicus and amplified by PCR using the designed forward (5' GGG GAA TTC ATG AGA ACA TTA AAA AAC CTC 3') and reverse (5'GCC AAG CTT ATT ATA ATA ATT TTT TAC GTG TTC CCC 3') primers, which named HasA_01F and HasA_01R, respectively. With the bacteria $S$. zooepidemicus used as the template, polymerase chain reaction (PCR) was performed with KOD Hot Start DNA polymerase in a thermal cycler using the following program: 1 cycle at $95^{\circ} \mathrm{C}$ for $3 \mathrm{~min}, 30$ cycles of $95^{\circ} \mathrm{C}$ for $15 \mathrm{sec}, 60^{\circ} \mathrm{C}$ for $30 \mathrm{sec}, 72^{\circ} \mathrm{C}$ for $90 \mathrm{sec}$ and $1 \mathrm{cycle}$ of $72{ }^{\circ} \mathrm{C}$ for $5 \mathrm{~min}$. PCR product was analyzed on $1 \%(\mathrm{w} / \mathrm{v})$ agarose gel and viewed using gel documentation system. 
Malays. J. Microbiol. Vol 15(7) 2019, pp. 575-582

DOI: http://dx.doi.org/10.21161/mjm.190444

\section{Cloning and transformation of hasA gene}

The PCR product and the plasmid pLbADH were digested separately with FastDigest enzyme EcoRI and HindIII (New England Biolabs, United States) in an incubator at $37^{\circ} \mathrm{C}$ for $1 \mathrm{~h}$. The enzymes were then heat inactivated at $80{ }^{\circ} \mathrm{C}$. Both digestion products were ligated together using T4 DNA ligase enzyme (Fermentas, United States) at $22{ }^{\circ} \mathrm{C}$ for overnight. The ligation product was then used for transformation. The ligation product was transformed into E. coli BL21 competent cells using heat shock method. The transformed E. coli BL21 culture was spread onto a Luria-Bertani (LB) agar plate containing $100 \mathrm{mg} / \mathrm{ml}$ ampicillin. All the colonies grown on the LB agar plates were collected and screened with PCR using the following program: 1 cycle at $95^{\circ} \mathrm{C}$ for $3 \mathrm{~min}, 30$ cycles of $95^{\circ} \mathrm{C}$ for $15 \mathrm{sec}, 60^{\circ} \mathrm{C}$ for $30 \mathrm{sec}, 72^{\circ} \mathrm{C}$ for $90 \mathrm{sec}$ and $1 \mathrm{cycle}$ of $72{ }^{\circ} \mathrm{C}$ for $5 \mathrm{~min}$. HasA_01F and HasA_01R were used as primer in selection of positive transformant. PCR products were analysed with $1 \%$ agarose gel electrophoresis.

\section{Medium and fermentation}

Recombinant E.coli was grown at $37^{\circ} \mathrm{C}$ with agitation for $5 \mathrm{~h}$ in the LB broth (as an inoculum) that supplemented with $100 \mathrm{mg} / \mathrm{mL}$ of ampicillin. The fermentation medium contained two different types of components; one is LB and glucose (10-50 g/L) only; one is nutrient rich medium which consisted of (in $\mathrm{g} / \mathrm{L}$ ) glucose 50 , tryptone 15 , yeast extract $5, \mathrm{KH}_{2} \mathrm{PO}_{4} \quad 2, \mathrm{~K}_{2} \mathrm{HPO}_{4} 2, \mathrm{MgSO}_{4} \cdot 7 \mathrm{H}_{2} \mathrm{O} 0.5$. Fermentations were carried out in triplicates and the mean value of each experiment was obtained. To investigate the effect of glucose concentrations (10-50 $\mathrm{g} / \mathrm{L}$ ) for HA biosynthesis by the recombinant $E$. coli strain, experiments were carried out using a $500 \mathrm{~mL}$ erlenmeyer flask. The flask cultures were incubated in rotary shaker at $200 \mathrm{rev} / \mathrm{min}$ with different glucose concentrations. To initiate the fermentation, 1 loop of colony culture was transferred to $50 \mathrm{~mL}$ of LB inoculum medium for $5 \mathrm{~h}$ at $\mathrm{pH}$ 7 and $10 \%(\mathrm{v} / \mathrm{v})$ of inoculum was inoculated into the 500 $\mathrm{mL}$ shake flask containing $180 \mathrm{~mL}$ of the production medium and run for another 7 hours at initial $\mathrm{pH} 7,37^{\circ} \mathrm{C}$. Four different isopropyl $\beta$-D-1-thiogalactopyranoside (IPTG) concentrations (0, $0.1,0.5$ and $1.0 \mathrm{mM})$ were investigated in the optimized medium and incubated at 37 ${ }^{\circ} \mathrm{C}, 200 \mathrm{rev} / \mathrm{min}$ and with initial $\mathrm{pH}$ 7. IPTG was added to induce the expression of has $A$ genes when OD600 reached about 0.6.

\section{Analytical methods}

All samples were withdrawn at regular time intervals for analysis of cell, HA and glucose concentration. Cell growth was observed by measuring the optical density of the culture broth at $600 \mathrm{~nm}$ using a spectrophotometer. Correlation between the dry cell weight (DCW) and OD was estimated from several batch experiments using the equation: $\mathrm{DCW}(\mathrm{g} / \mathrm{L})=2.2511 \times \mathrm{OD}$.

The supernatants were used for $\mathrm{HA}$ and reducing sugar determination. After the removal of the cell pellet for cell

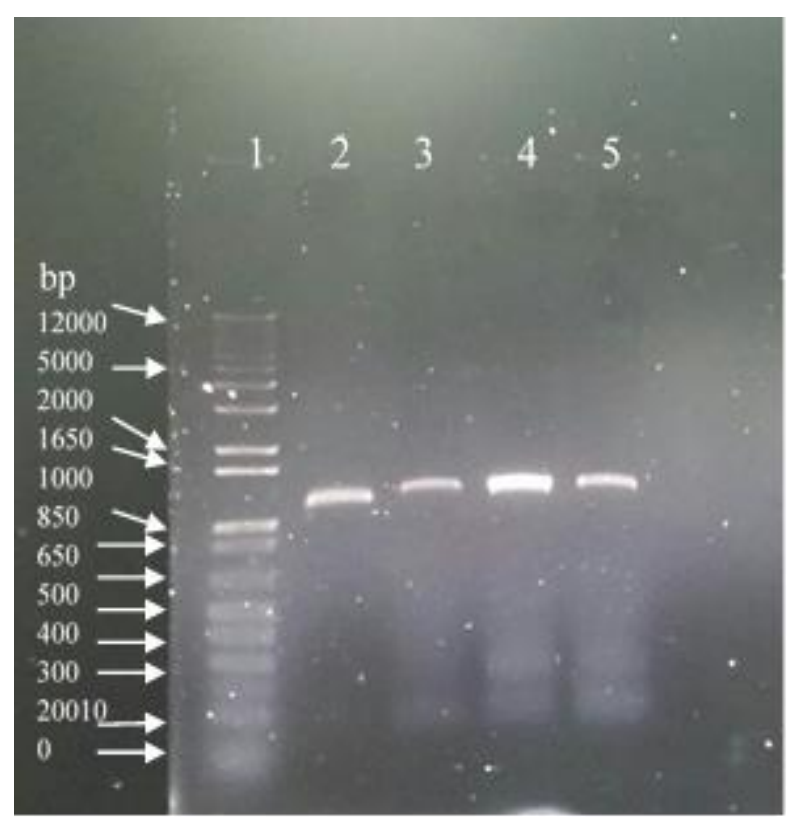

Figure 2A: Screening for positive transformant. Lane 1: $1 \mathrm{~kb}$ plus DNA ladder; Lane 2: positive control of hasA gene; lane 3-5: Samples 1-3.

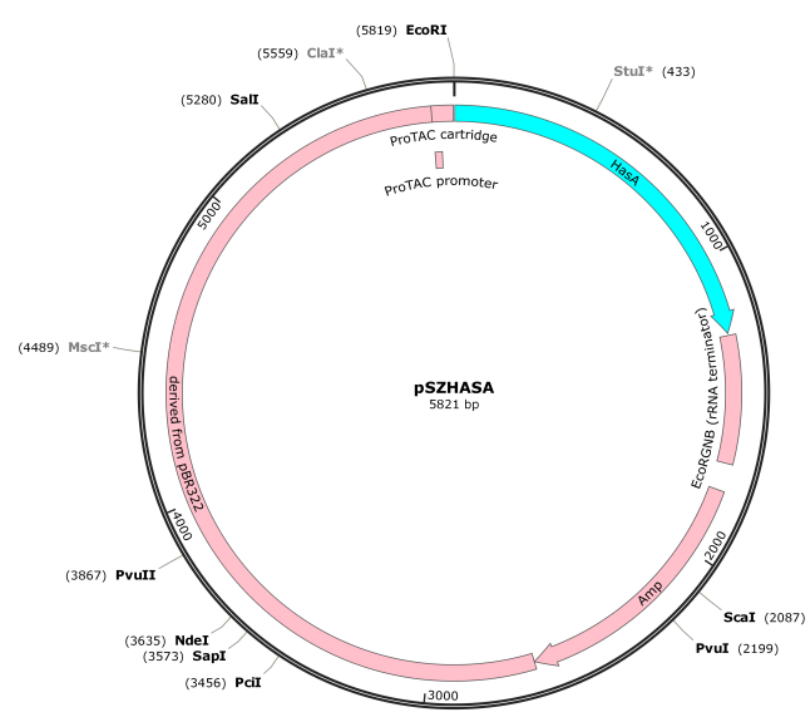

Figure 2B: Vector map of pSzHasA.

growth determination, two volumes of ethanol were added to one volume of the supernatant in a $15 \mathrm{~mL}$ centrifuge tube and the solution was refrigerated at $4{ }^{\circ} \mathrm{C}$ for $1 \mathrm{~h}$ to precipitate HA. The precipitate was re-dissolved in $1 \mathrm{~mL}$ of $0.15 \mathrm{~mol} / \mathrm{L}$ of $\mathrm{NaCl}$ solution and centrifuged at 3,000 $\times$ $g$ for $20 \mathrm{~min}$; then was re-dissolved with a 2 to 3 -fold volume of distilled water. The HA concentration was determined using the carbazole method (Bitter and Muir, 1962) and the optical density was measured at $530 \mathrm{~nm}$. The HA concentration was calculated using a standard 
curve prepared at different concentrations of HA standards (Sigma-Aldrich, Malaysia). For reducing sugar concentration, 3,5-dinitrosalicylic acid (DNS) method was used (Miller, 1959). The HA molecular weight was analyzed by following Lai et al. (2012) method.

\section{RESULTS AND DISCUSSION}

\section{Cloning of hasA gene from S. zooepidemicus}

The has $A$ gene from $S$. zooepidemicus was successfully amplified by PCR and cloned into the plasmid pLbADH as shown in Figure $2 \mathrm{~A}$. In this study, the original hasA gene from $S$. zooepidemicus was used to produce HA in recombinant $E$. coli with no change in Codon Adaptation index (CAI). The expression of has $A$ gene is driven by the TAC promoter with the vector of pSzHasA as shown in Figure 2B. There was several plasmid constructed containing different promoters to transformed has $A$ gene into other recombinant hosts. Jeong et al. (2014) utilized two types of plasmid, pAO815 and pGAPZB which have an inducible promoter (AOX) and a constitutive promoter (GAP), respectively. They used the vector with constitutive promoters to accumulate both sugar precursors of $\mathrm{HA}$ in the cell, then activate the inducible promoter preceding the hasA gene, leading to an increased production and higher MW of HA. In this study, a strong $E$. coli TAC promoter was used to provide strong expression of hasA gene in E. coli BL21 host.

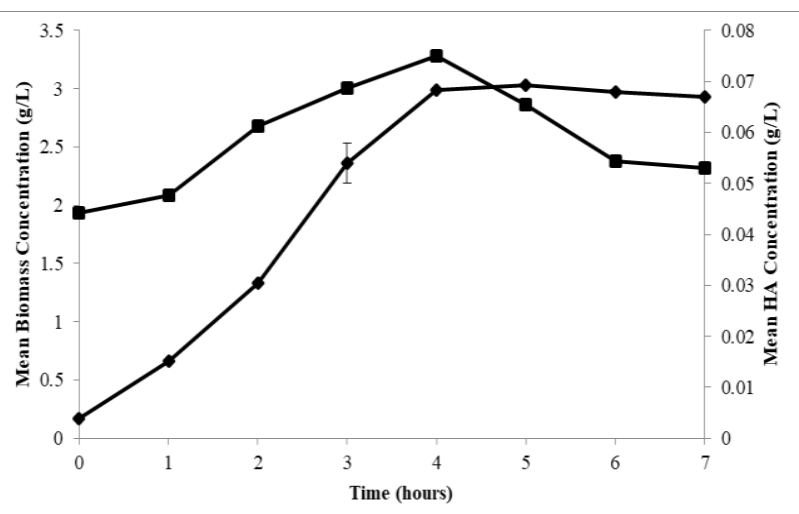

Figure 3: Graph of mean biomass and HA concentration $(\mathrm{g} / \mathrm{L})$ by recombinant $E$. coli BL21 in shake flask culture using $50 \mathrm{~g} / \mathrm{L}$ glucose. All concentrations were represented as the mean value of triplicated results from independent fermentation. - HA (») Biomass

Effect of different glucose concentrations on HA production by recombinant $E$. coli BL21

Based on the kinetic parameter values (Table 1), highest biomass concentration $(\mathrm{Xm})$ and highest $\mathrm{HA}$ concentration $(\mathrm{Pm})$ was $3.031 \pm 0.004 \mathrm{~g} / \mathrm{L}$ and $0.074 \pm$ $0.001 \mathrm{~g} / \mathrm{L}$, respectively, both achieved at $50 \mathrm{~g} / \mathrm{L}$ glucose Concentration. However, lowest $\mathrm{Xm}$ and $\mathrm{Pm}$ was 2.161 $\pm 0.002 \mathrm{~g} / \mathrm{L}$ and $0.018 \pm 0.013 \mathrm{~g} / \mathrm{L}$ respectively, both

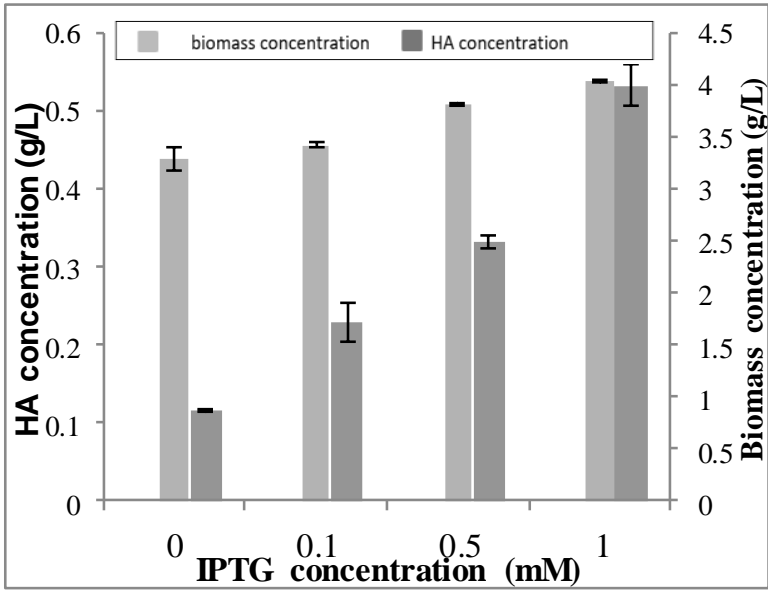

Figure 4: Comparison of $\mathrm{HA}$ concentration $(\mathrm{g} / \mathrm{L})$ using different IPTG concentration in $50 \mathrm{~g} / \mathrm{L}$ of glucose concentration with nutrient rich media. All HA concentrations were represented as the mean value of triplicated results from independent fermentation.

achieved in control condition. This is in accordance to our expected results, as the bacteria requires carbon source for cell growth and HA production. In control, there was no glucose present, so there was insufficient precursor for $\mathrm{HA}$ production. However, as glucose concentration increased, the precursors, GlcUA and GlcNAc were made and $\mathrm{HA}$ concentration increased. According to a study conducted by Mashitah and Noor (2010), highest HA concentration of $0.589 \mathrm{~g} / \mathrm{L}$ was achieved at $50 \mathrm{~g} / \mathrm{L}$ glucose concentration. However, in their experiment, when glucose concentration was increased to $60 \mathrm{~g} / \mathrm{L}, \mathrm{HA}$ concentration decreased.

Highest cell yield coefficient $\left(Y_{x / S}\right)$ was achieved at 20 $\mathrm{g} / \mathrm{L}$ glucose concentration. This result suggests that highest $Y_{X / S}$ does not mean highest productivity. At $50 \mathrm{~g} / \mathrm{L}$, the $Y x / s$ value was the least, $0.313 \mathrm{~g}$ cell/ $\mathrm{g}$ substrate, suggesting that less cells were produced per gram of glucose. It could be concluded that glucose concentration above $50 \mathrm{~g} / \mathrm{L}$ causes reduction in water activity which may lead to growth inhibition. Glucose is a monosaccharide and hence its' osmotic pressure will be higher, so microorganisms will detect the changes in osmotic pressure and alter their metabolic pathway. Ding and Tan (2006) also stated that high initial glucose concentration in batch fermentation method can cause low cell mass due to substrate inhibition.

At $50 \mathrm{~g} / \mathrm{L}$, product yield per substrate produced (YP/S) and maximum productivity $(\mathrm{Pr})$ had maximum values of $0.004 \mathrm{~g} \mathrm{HA} / \mathrm{g}$ cell and $0.018 \mathrm{~g} \mathrm{HA} / \mathrm{L} / \mathrm{h}$, respectively. At 40 $\mathrm{g} / \mathrm{L}$, YP/S was $0.003 \mathrm{~g} \mathrm{HA} / \mathrm{g}$ cell and at $50 \mathrm{~g} / \mathrm{L}$, Y $\mathrm{P} / \mathrm{S}$ was $0.004 \mathrm{~g} \mathrm{HA} / \mathrm{g}$ cell suggesting that glucose was more efficiently consumed at $50 \mathrm{~g} / \mathrm{L}$. Values for product yield per biomass produced $\left(Y_{P / X}\right)$ increased with increase in glucose concentration, reaching a maximum value of $0.010 \mathrm{~g} \mathrm{HA} / \mathrm{g}$ cell at $50 \mathrm{~g} / \mathrm{L}$ glucose concentration. This suggested that as the number of cells increased, the 
Malays. J. Microbiol. Vol 15(7) 2019, pp. 575-582

DOI: http://dx.doi.org/10.21161/mjm.190444

Table 1: Kinetic parameter values of HA production by recombinant $E$. coli BL21 using different glucose concentrations.

\begin{tabular}{|c|c|c|c|c|c|}
\hline \multirow{2}{*}{ Kinetic parameters } & \multicolumn{5}{|c|}{ Glucose concentration (g/L) } \\
\hline & 10 & 20 & 30 & 40 & 50 \\
\hline $\mathrm{X}_{m}(\mathrm{~g}$ cell /L) & $2.501 \pm 0.010$ & $2.602 \pm 0.011$ & $2.656 \pm 0.002$ & $2.879 \pm 0.004$ & $3.031 \pm 0.004$ \\
\hline $\mathrm{P}_{m}(\mathrm{~g} \mathrm{HA} / \mathrm{L})$ & $0.026^{e} \pm 0.001$ & $0.029^{d} \pm 0.0001$ & $0.037^{c} \pm 0.0001$ & $0.057^{b} \pm 0.003$ & $0.074^{\mathrm{a}} \pm 0.001$ \\
\hline$\mu_{m}(1 / h)$ & 0.500 & 0.520 & 0.531 & 0.575 & 0.606 \\
\hline $\begin{array}{c}\mathrm{YX/S}_{X}(\mathrm{~g} \text { cell/g } \\
\text { substrate })\end{array}$ & 0.669 & 0.682 & 0.415 & 0.446 & 0.313 \\
\hline $\begin{array}{l}\mathrm{Y}_{P / S}(\mathrm{~g} \mathrm{HA} / \mathrm{g} \\
\text { substrate) }\end{array}$ & 0.001 & 0.001 & 0.001 & 0.003 & 0.004 \\
\hline$Y_{P / X}(\mathrm{~g} \mathrm{HA} / \mathrm{g}$ cell $)$ & 0.002 & 0.002 & 0.004 & 0.005 & 0.010 \\
\hline $\operatorname{Pr}(\mathrm{g} \mathrm{HA} / \mathrm{L} / \mathrm{h})$ & 0.006 & 0.007 & 0.009 & 0.014 & 0.018 \\
\hline
\end{tabular}

All results are expressed as means \pm standard deviation of means; Values are means of triplicates from three separate runs $(n=3)$. $p$ value for average HA concentration in accordance to glucose concentration was obtained using two way ANOVA statistical analysis $(\alpha=0.05)$. a, b, c, $d$ and e: Values with different lowercase superscript are significantly different.

Table 2: Kinetic parameter values of HA production by recombinant E. coli BL21 using different media.

\begin{tabular}{lll}
\hline Kinetic parameters & \multicolumn{2}{c}{ Glucose concentration $(\mathrm{g} / \mathrm{L})$} \\
\cline { 2 - 3 } & 50 without nutrient rich components & 50 \& nutrient rich media \\
\hline $\mathrm{X}_{m}(\mathrm{~g} \mathrm{cell} / \mathrm{L})$ & $3.031 \pm 0.004$ & $3.280 \pm 0.108$ \\
$\mathrm{P}_{m}(\mathrm{~g} \mathrm{HA} / \mathrm{L})$ & $0.074^{\mathrm{b}} \pm 0.001$ & $0.115^{\mathrm{a}} \pm 0.002$ \\
$\mu_{m}(1 / \mathrm{h})$ & 0.606 & 0.546 \\
$Y_{X / S}(\mathrm{~g} \mathrm{cell} / \mathrm{g}$ substrate $)$ & 0.313 & 0.259 \\
$Y_{P / S}(\mathrm{~g} \mathrm{HA} / \mathrm{g}$ substrate $)$ & 0.004 & 0.006 \\
$Y_{P / X}(\mathrm{~g} \mathrm{HA} / \mathrm{g}$ cell $)$ & 0.010 & 0.0195 \\
$\mathrm{P}_{r}(\mathrm{~g} \mathrm{HA} / \mathrm{L} / \mathrm{h})$ & 0.018 & 0.0287
\end{tabular}

All results are expressed as means \pm standard deviation of means; Values are means of triplicates from three separate runs $(n=3)$. $p$ value for average HA concentration in accordance to different media was obtained using two way ANOVA statistical analysis ( $\alpha=0.05$ ). $a$ and b: values with different lowercase superscript are significantly different.

Table 3: HA concentration and molecular weight in different IPTG concentrations

\begin{tabular}{lll}
\hline IPTG concentration $(\mathrm{mM})$ & HA concentration $(\mathrm{g} / \mathrm{L})$ & HA molecular weight $(\mathrm{kDa})$ \\
\hline 0 & $0.115^{\mathrm{d}}$ & $8.7^{\mathrm{d}}$ \\
0.1 & $0.229^{\mathrm{c}}$ & $12.5^{\mathrm{c}}$ \\
0.5 & $0.331^{\mathrm{b}}$ & $17.3^{\mathrm{b}}$ \\
1.0 & $0.532^{\mathrm{a}}$ & $34.6^{\mathrm{a}}$ \\
\hline
\end{tabular}

All results are expressed as means \pm standard deviation of means; Values are means of triplicates from three separate runs $(n=3)$. $p$ value for average HA concentration and molecular weight in accordance to IPTG concentration was obtained using one way ANOVA statistical analysis $(\alpha=0.05)$. a, b, $c$ and $d$ : values with different lowercase superscript in same column are significantly different.

amount of HA production also increased. Hence, the results showed that $\mathrm{HA}$ fermentation by recombinant $E$. coli BL21 is highly growth associated as shown in Figure 3. However, studies conducted by Huang et al. (2007) suggested that HA production was delayed-growth associated which was in accordance to several other reports.

At $50 \mathrm{~g} / \mathrm{L}, \mathrm{Y}_{\mathrm{X} / \mathrm{S}}$ was the least and $\mathrm{Y}_{\mathrm{P} / \mathrm{S}}$ was the highest suggesting glucose was mainly used for HA production. Precursors such as glucose-1-phosphate, UDP-glucose and UDP-N-acetylglucosamine are shared in HA 
synthesis and cell growth. Hence, competition between these two pathways exists to consume the same precursors. In addition, competition for carbon flux exists between HA synthesis and glycolysis. Metabolites such as glucose-6-phosphate and fructose-6-phosphate are consumed by hexomonophosphate shunt and glycolysis, respectively. Hence, there is strong competition for metabolites between HA production and cell growth. HA production is an energy intensive process and total of 4 mol ATP is required for production of $1 \mathrm{~mol}$ of repeating unit of HA disaccharide. Therefore, in order to balance between biomass and HA production, maintenance of metabolic balance is important as well (Izawa et al., 2011).

\section{Effect of nutrient rich media on HA fermentation by recombinant $E$. coli BL21}

The use of nutrient rich media for HA production yielded higher biomass concentration and HA concentration when compared to use of glucose alone. As shown in Table 2, maximum biomass concentration $(\mathrm{Xm})$ was $3.280 \pm 0.108$ $\mathrm{g} / \mathrm{L}$ when $50 \mathrm{~g} / \mathrm{L}$ glucose along with nutrient rich media was used. However, when only $50 \mathrm{~g} / \mathrm{L}$ glucose was used, the biomass concentration was $3.031 \pm 0.004 \mathrm{~g} / \mathrm{L}$. Studies by other researchers were conducted with constant glucose concentration and varying yeast extract concentration (as nitrogen source). The results supported our findings, suggesting that presence of organic nitrogen source improves the microorganism growth, with maximum cell growth when $\mathrm{C}: \mathrm{N}$ ratio is $2: 1$ (Chen et al., 2009). The increase in biomass concentration is because yeast extract is a good substrate for many microorganisms as it contains important components such as amino acid, peptide, water-soluble vitamins and carbon source which are required for growth and metabolism. With nutrient rich media, maximum HA concentration $(\mathrm{Pm})$ was $0.115 \pm 0.002 \mathrm{~g} \mathrm{HA} / \mathrm{L}$, whereas with $50 \mathrm{~g} / \mathrm{L}$ glucose concentration it was only $0.074 \pm$ $0.001 \mathrm{~g} \mathrm{HA} / \mathrm{L}$. This might have been due to availability of amino acid and B-vitamins provided by organic nitrogen source, yeast extract and tryptone. Additionally, presence of these organic nitrogen sources provides large portion of carbon for the growth and production of cells. The specific growth rate $(\mu \mathrm{m})$ was slightly higher at $50 \mathrm{~g} / \mathrm{L}$ glucose concentration. This can be explained by the cell yield coefficient $\left(Y_{X / S}\right)$ which is also higher for $50 \mathrm{~g} / \mathrm{L}$ glucose concentration, which suggests that more cells are produced per substrate consumed at $50 \mathrm{~g} / \mathrm{L}$. In nutrient rich media, more of the metabolised carbon source might have been used for HA production, as a result slightly lower specific growth rate was achieved. The product yield coefficient (YP/S) and product yield per biomass coefficient (YP/S) was higher with nutrient rich media containing $50 \mathrm{~g} / \mathrm{L}$ glucose. The productivity is also higher in nutrient rich media, with a value of $0.028 \mathrm{~g} \mathrm{HA} / \mathrm{L} / \mathrm{h}$ which is in accordance to results obtained by other researchers which suggests that presence of nitrogen source increases the production of HA (Pan et al., 2014).
There is limited information about the consequence of medium carbon-to-nitrogen $(\mathrm{C} / \mathrm{N})$ ratios which will cause an effect on the metabolic flux. Studies showed that presence of potassium dihydrogen phosphate $\left(\mathrm{KH}_{2} \mathrm{PO}_{4}\right)$ and magnesium sulphate heptahydrate $\left(\mathrm{MgSO}_{4} \cdot 7 \mathrm{H}_{2} \mathrm{O}\right)$ also contribute to increase in biomass and HA productivity (Aroskar et al., 2012). Hence, the presence of these substances in nutrient rich media may have also contributed to higher biomass and HA concentration.

\section{Effects of different IPTG concentrations on HA fermentation}

Different IPTG concentrations are used to induce the expression of hasA in recombinant $E$. coli in nutrient rich media. As shown in Figure 4, $1.0 \mathrm{mM}$ of IPTG was able to achieved the highest biomass concentration $\left(X_{m}\right)(4.03 \pm$ $0.020 \mathrm{~g} / \mathrm{L})$, the highest HA concentration $\left(\mathrm{P}_{\mathrm{m}}\right)(0.532 \pm$ $0.026 \mathrm{~g} / \mathrm{L})$, and the highest productivity $\left(P_{r}\right)(0.076 \mathrm{~g} / \mathrm{L} / \mathrm{h})$. This is expected as IPTG acts as an inducer to induce the higher expression of HAS genes in recombinant E. coli, thus producing more HA. The result obtained was significantly higher when compared to $\mathrm{Yu}$ and Stephanopoulos (2008), as they were able to produce $95.9 \mathrm{mg} / \mathrm{L}$ of HA. In contrast, the control experiment (without the addition of IPTG) showed a lower biomass concentration of $3.28 \pm 0.024 \mathrm{~g} / \mathrm{L}$ with $\mathrm{HA}$ concentration $(\mathrm{Pm})$ of $0.115 \pm 0.002 \mathrm{~g} / \mathrm{L}$, and HA productivity $(\mathrm{Pr})$ of $0.028 \mathrm{~g} / \mathrm{L} / \mathrm{h}$. A possible explanation is that recombinant $E$. coli BL21 is able to express the has genes without any help from IPTG inducer.

In nutrient rich medium with $50 \mathrm{~g} / \mathrm{L}$ of glucose, the medium with added $1.0 \mathrm{mM}$ of IPTG produced the highest among the rest. It is an advantage as higher biomass allows IPTG to rapidly enter into the cell (FernándezCastané et al., 2012). Moreover, it revealed that the lac promoter was fully induced by $1.0 \mathrm{mM}$ of IPTG and there was a competition for metabolites between biomass growth and HA production. According to Madurawe et al. (2000) the concentrations of IPTG (between 0.1-2.0 mM) vary differently with clones in order for a complete induction.

Comparing the control experiment with $0.1 \mathrm{mM}$ of IPTG, the production of biomass and HA is almost similar. This could be due to the fact that HA expression is not fully induced by IPTG as the intracellular inducer does not bind tightly to the receptor to release all the repressor molecules from various operator sites. Another possibility is that when using low concentrations of IPTG, it is not enough to induce all the cells, thus leaving some of the cells un-induced (Fernández-Castané et al., 2012). On the other hand, reduction of the biomass concentration will occur if there is an excess of IPTG present in the medium. A study carried out by Yee and Blanch (1993) supports that statement where they used IPTG concentration more than $1.0 \mathrm{mM}$, resulting in reduced growth rate in E. coli. Therefore, production of HA can be regulated from low to highly induced expression level by altering the IPTG concentration. Molecular weight is an important parameter for microbial HA synthesis because it 
determines the quality of $\mathrm{HA}$. Low molecular weight $\mathrm{HA}$ is widely used in cosmetics as moisturizers and possesses pronounced free radical scavenging and antioxidant activities. In this study, the HA molecular weight $34.6 \mathrm{kDa}$ obtained at $50 \mathrm{~g} / \mathrm{L}$ glucose with nutrient rich media plus $1.0 \mathrm{mM}$ IPTG (Table 3). This result is comparable to Lai et al. (2016) who were able to produce $40.9 \mathrm{kDa} H A$ using combination of hasA and hasE genes in recombinant E.coli.

\section{CONCLUSION}

The has $A$ gene was cloned from S. zooepidemicus and successfully expressed in recombinant $E$. coli BL21 cells. $50 \mathrm{~g} / \mathrm{L}$ glucose concentration along with nitrogen source such as yeast and tryptone is the preferred combination to produce the highest concentration of HA through fermentation by recombinant $E$. coli BL21 using shake flask culture. The results obtained from this study showed that high HA production $(0.115 \pm 0.002 \mathrm{~g} / \mathrm{L})$ was achieved in nutrient rich media with $50 \mathrm{~g} / \mathrm{L}$ glucose concentration. With addition of $1.0 \mathrm{mM}$ IPTG, the highest HA production $(0.532 \pm 0.026 \mathrm{~g} / \mathrm{L})$ and molecular weight at $34.6 \mathrm{kDa}$ was achieved which is around fivefold higher compared to without IPTG. To further improve the productivity of HA in recombinant $E$. coli, gene integrative system will be used for hasA gene and hasABC gene cassette in future.

\section{ACKNOWLEDGEMENTS}

This work was financially supported by Major funding scheme funded by Taylor's university lakeside campus. (TRGS/MFS/2/2016/SBS/005).

\section{REFERENCES}

Aroskar, V. J., Kamat, S. D. and Kamat, D.V. (2012). Effect of various physical parameters and statistical medium optimization on production of hyaluronic acid using S. equi subsp. zooepidemicus ATCC 39920. IIOAB Letter 2(1), 7-15.

Bitter, T. and Muir, H. M. (1962). A modified uronic acid carbazole reaction. Analytica Biochemistry 4(4), 330334.

Chen, S. J., Chen, J. L., Huang, W. C. and Chen, H. L. (2009). Fermentation process development of hyaluronic acid production by Streptococcus zooepidemicus ATCC 39920. Korean Journal of Chemical Engineering 26(2), 428-432.

Chong, B. F., Blank, L. M., Mclaughlin, R. and Nielsel, L. K. (2005). Microbial hyaluronic acid production. Applied Microbial Biotechnology 66, 341-351.

DeAngelis, P. L. (1999.) Molecular directionality of polysaccharide polymerization by the Pasteurella multocida hyaluronan synthase. The Journal of Biological Chemistry 274(37), 26557-26562.

Ding, S. and Tan, T. (2006). L-Lactic acid production by Lactobacillus casei fermentation using different fedbatch feeding strategies. Process Biochemistry 41(6), 1451-1454.
Fernández-Castané, A., Caminal, G. and LópezSantín, J. (2012). Direct measurements of IPTG enable analysis of the induction behaviour of $E$. coli in high density cultures. Microbial Cell Factories 11(1), 58.

Grand View Research. (2019, May). Hyaluronic acid market size worth $\$ 15.25$ billion by 2026 . https://www.grandviewresearch.com/pressrelease/glo bal-hyaluronic-acid-market. [Retrieved on 2 June 2019].

Hmar, R. V., Prasad, S. B., Jayaraman, G. and Ramachandran, K. B. (2014). Chromosomal integration of hyaluronic acid synthesis (has) genes enhances the molecular weight of hyaluronan produced in Lactococcus lactis. Biotechnology Journal 9(12), 1-11.

Huang, W. C., Chen, S. J. and Chen, T. L. (2007). Modelling the microbial production of hyaluronic acid. Journal of the Chinese Institute of Chemical Engineers 38, 355-359.

Izawa, M., Serata, M., Sone, T., Omasa, T. and Ohtake, H. (2011). Hyaluronic acid production by recombinant Streptococcus thermophiles. Journal of Bioscience and Bioengineering 111(6), 665-670.

Jeong, E., Shim, W. Y. and Kim, J. H. (2014). Metabolic engineering of Pichia pastoris for production of hyaluronic acid with high molecular weight. Journal of Biotechnology 185, 28-36.

Kumari, K. and Weigel, P. H. (1997). Molecular cloning, expression, and characterization of the authentic hyaluronan synthase from Group C Streptococcus equisimilis. Journal of Biological Chemistry 272, 32539-32546.

Lai, Z. W., Rahim, R. A., Ariff, A. and Mohamad, R. (2011). Medium formulation and impeller design on the biosynthesis of high molecular weight hyaluronic acid by Streptococcus zooepidemicus ATCC 39920. African Journal of Microbiology Research 5(5), 21142123.

Lai, Z. W., Rahim, R. A., Ariff, A. and Mohamad, R. (2012). Biosynthesis of high molecular weight hyaluronic acid by Streptococcus zooepidemicus using oxygen vector and optimum impeller tip speed. Journal of Bioscience and Bioengineering. 114(3), 286-291.

Lai, Z. W., Rahim, R. A., Ariff, A. and Mohamad, R. (2016). Comparison of hyaluronic acid biosynthesis by the recombinant Escherichia coli strains in different mode of bioreactor operation. Journal of Microbiology, Biotechnology and Food Sciences 6(3), 905-910.

Liu, L., Liu, Y., Li, J., Du, G. and Chen, J. (2011). Microbial production of hyaluronic acid: Current state, challenges, and perspectives. Microbial Cell Factories 10(1), 99.

Madurawe, R. D., Chase, T. E., Tsao, E. I. and Bently, W. E. (2000). A recombinant lipoprotein antigen against lyme disease expressed in E.coli: Fermentor operating strategies for improved yield. Biotechnology Progress 16(4), 571-576. 
Malays. J. Microbiol. Vol 15(7) 2019, pp. 575-582

DOI: http://dx.doi.org/10.21161/mjm.190444

Mao, Z., Shin, H. and Chen, R. (2009). A recombinant $E$. coli bioprocess for hyaluronan synthesis. Applied Microbiology and Biotechnology 84(1), 63-69.

Mashitah, M. D. and Noor, F. S. (2010). Kinetics of hyaluronic acid production by Streptococcus zooepidemicus considering the effect of glucose. Biochemical Engineering Journal 49(1), 95-103.

Miller, G. L. (1959). Use of dinitrosalicylic acid reagent for determination of reducing sugars. Analytical Chemistry 31, 426-428.

Pan, N. C., Marques, R., Pereira, H. C. B. , Vignoli, J. A. and Celligoi, M. A. P. C. (2014). Effects of different nitrogen sources on the production of hyaluronic acid by Streptococcus. BMC Proceedings 8(4), 204.

Rosa, C. S., Tovar, A. F., Mourao, P., Pereira, R., Barreto, P. and Beirao, L. H. (2012). Purification and characterization of hyaluronic acid from chicken combs. Ciencia Rural 42(9), 1682-1687.

Widner, B., Behr, R., Dollen, S. V., Tang, M., Heu, T., Sloma, A., Sternberg, D., DeAngelis, P. L., Weigl, P. H. and Brown, S. (2005). Hyaluronic acid production in Bacillus subtilis. Applied and Environmental Microbiology 71(7), 3747-3752.

Yamada, T. and Kawasaki, T. (2005). Microbial synthesis of hyaluronan and chitin. Journal of Bioscience and Bioengineering 99(6), 521-528.

Yee, L. and Blanch, H. W. (1993). Defined media optimization for growth of recombinant Escherichia coli X90. Biotechnology and Bioengineering 41(2), 221-230.

Yu, H. and Stephanopoulos, G. (2008). Metabolic engineering of Escherichia coli for biosynthesis of hyaluronic acid. Metabolic Engineering 10(1), 24-32. 